\section{A Preliminary Communication on a Conductrimetric Screening Test for Electrolytes}

\author{
EDDA BOESEN AND PATRICIA A. LOUD \\ From the Central Laboratory, Portsmouth
}

(RECEIVED FOR PUBLICATION JUNE 2, 1955)

In recent years the clinical significance of the electrolyte balance of the blood has become increasingly realized, and was the subject of a leader in the Lancet. This has also been stressed by other workers (Baumann, 1952; Black, 1953; Graham, 1954; Wynn and Rob, 1954).

The following investigation was carried out with a view to finding whether a rapid screening test could be of practical clinical use in differentiating plasma with a normal electrolyte balance from that containing an abnormal electrolyte balance. If this were so, it would result in a saving of time and skilled labour, as only serum showing abnormal electrolyte values would require further analysis.

\section{Historical}

The first work on the conductivity and resistance of serum was carried out by Burgarzky and Tangl in 1898 . More recently Davydoff (1951) described in detail a method for the measurement of the electrical resistance of plasma. The following year Davydoff in collaboration with Sautier produced an empirical formula sufficiently accurate for clinical application, which gave a correction factor for plasma proteins (Davydoff and Sautier, 1952). In the work to be described it was found necessary to modify this procedure and we have used the following method.

\section{Method}

Blood, $5 \mathrm{ml}$., was collected under paraffin in a tube containing $50 \mathrm{i} . \mathrm{u}$. of heparin. The tube was centrifuged as soon as possible after collection and the plasma separated. This was found to be essential, as both the storage temperature and the time factor were found to

TABLE I

EFFECT OF STORAGE AND TEMPERATURE

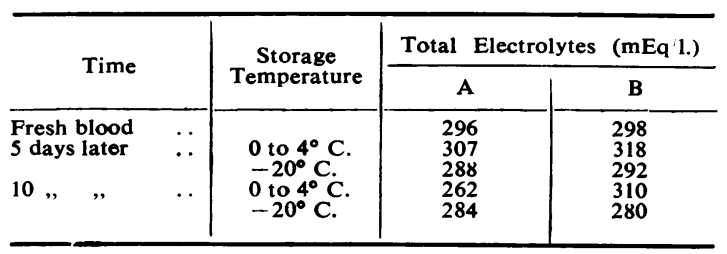

affect the results, as shown with these two control samples.

The plasma was placed in a small glass tube in a water-bath at $37^{\circ} \mathrm{C}$. and left for 10 minutes to reach this temperature, the vessel being plugged to prevent evaporation.

The cell used to measure the resistance of the plasma consisted of two equal square platinum electrodes fixed parallel to each other in the sides of a small glass container. The cell and container were thoroughly rinsed with doubly distilled water between each estimation. Plasma, 1.5 to $2 \mathrm{ml}$., was siphoned into the tube by a rubber teat, care being taken to avoid air bubbles which increase the resistance. An improved cell is now being designed by Messrs. Mullards and will reduce the time needed to warm the plasma to $37^{\circ} \mathrm{C}$.

The apparatus (Fig. 1) consisted basically of a wheatstone bridge circuit as shown in the diagram. An oscillating current of $1,000 \mathrm{c} / \mathrm{s}$ was supplied by a valve

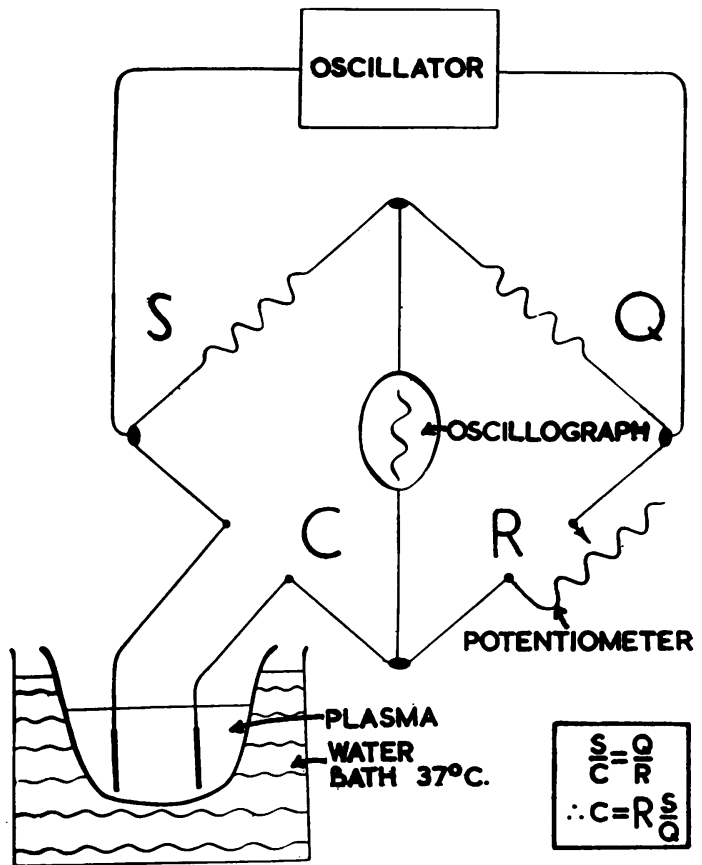

Fig. 1.-Diagram of the apparatus.

oscillator to prevent polarization at the electrodes. The point of balance was determined by an oscillograph. Three constant consecutive readings were obtained before the figure was included in our series, the plasma in the cell and container being mixed before each reading. The actual readings were obtained within a few minutes.

The resistance $R$ is measured on the potentiometer and multiplied by $S, Q$, giving the resistance of the cell C. This resistance, $C$, is multiplied by the cell constant $\mathrm{K}$, obtained by calibration against solutions of $\mathrm{KCl}$ of known strength. Thus the actual resistance of the plasma $\mathrm{p}=\mathrm{K} \mathrm{C}$.

The formula employed in working out the results for 
total electrolytes in milliequivalents per litre is that given by Davydoff and Sautier.

$$
\mathrm{mEq} / \mathrm{l}=\frac{10^{\mathrm{s}} \times 1.8}{\mathrm{p}(100-0.25 \mathrm{P})}
$$

where $p$ is the resistance of the plasma

$P$ is the proteins in $\mathbf{g} .1$.

Each of 118 specimens of blood was estimated in this way for total electrolyte content. At the same time the chief acid and base radicles, namely potassium, sodium, chlorides, and $\mathrm{CO}_{2}$-combining power, were estimated by the routine methods used in this laboratory. These acid and base radicles are more commonly assessed for the therapeutic control of post-operative cases, and are shown in Table II.

TABLE II

ASSESSMENT OF ACID AND BASE RADICLES

\begin{tabular}{|c|c|c|c|}
\hline & Normal Range & Mothod & Reference \\
\hline Proteins & 58 to 8.4 g. $\%$ & Biuret & Gornall et al. \\
\hline Potassium & 3.5 to $5 \mathrm{~m} . \mathrm{Eq} 1$ & $\begin{array}{l}\text { Flame } \\
\text { Photometer }\end{array}$ & Modified method \\
\hline Sodium .. & 136 to 145 & & $\begin{array}{l}\text { and Klyne } \\
\text { (1949) }\end{array}$ \\
\hline Chlorides & 95 to 105, & $\begin{array}{l}\text { Mercurometric } \\
\text { titration }\end{array}$ & $\begin{array}{l}\text { Schales and } \\
\text { Schales (1941) }\end{array}$ \\
\hline $\begin{array}{l}\text { Alkali } \\
\text { reserve }\end{array}$ & 22 to 30 & Volumetric & $\begin{array}{l}\text { Van Slyke and } \\
\text { Cullen (1917) }\end{array}$ \\
\hline
\end{tabular}

As shown in Fig. 2, of the 118 sera which were estimated, 81 were shown to have normal values for sodium, potassium, chloride, and $\mathrm{CO}_{2}$-combining power on biochemical analysis. Using this electrical screening

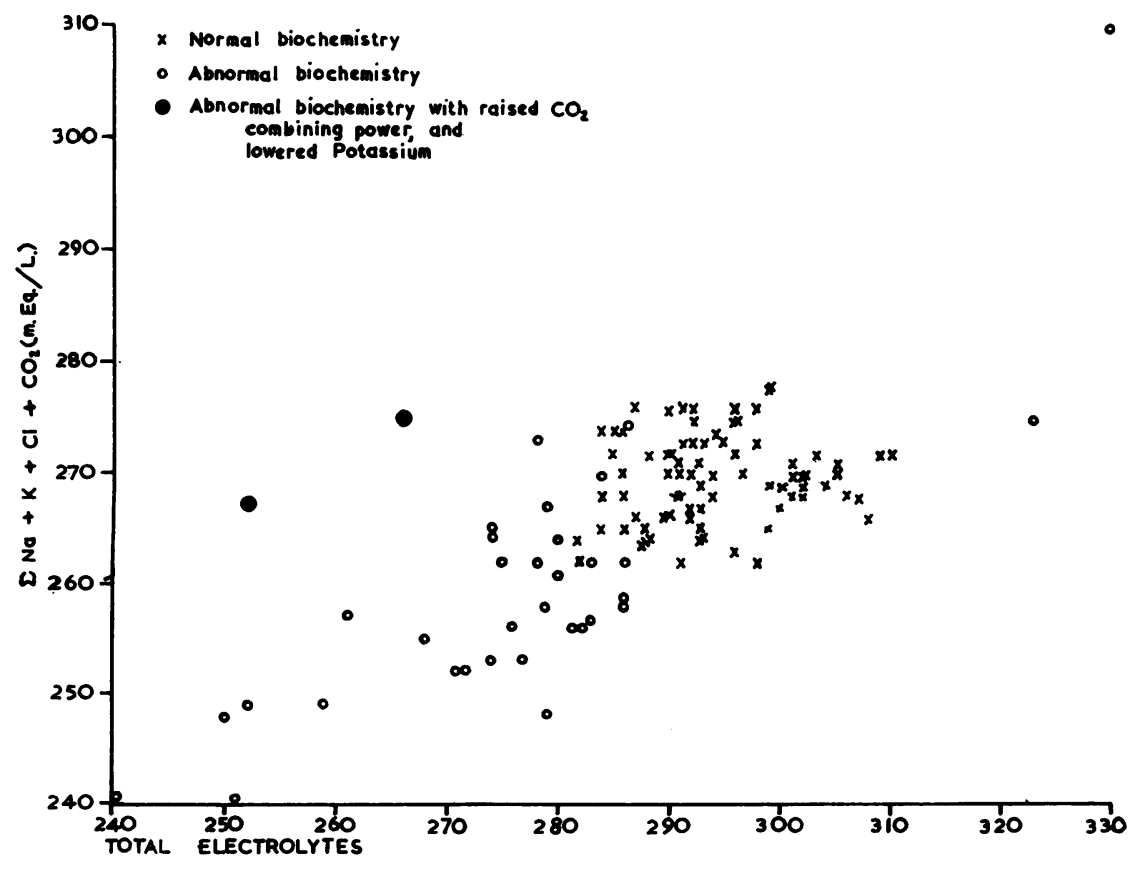

FIG. 3.-Scatter diagram showing results in normal and abnormal cases. method 61 of these normal sera gave total electrolyte $\stackrel{0}{\overrightarrow{5}}$ values between 290 and $310 \mathrm{~m} . \mathrm{Eq} / \mathrm{l}$. These figures substantially agree with Davydoff's normal range. $\frac{\overrightarrow{\bar{S}}}{\overrightarrow{0}}$

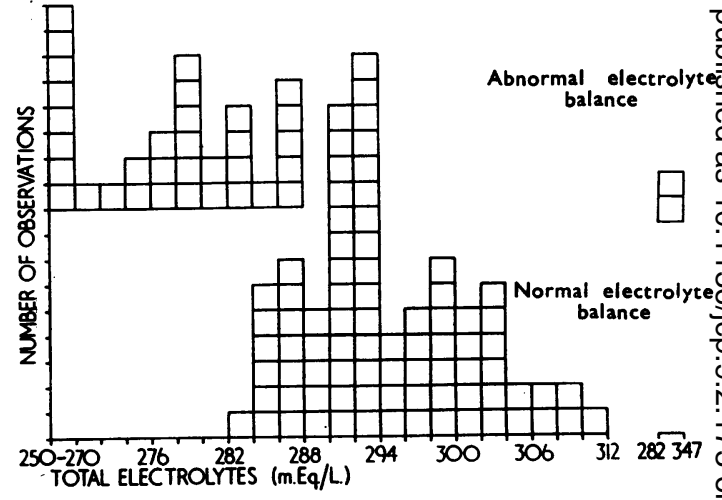

FIG. 2.-Results of 118 estimations (each square represents one estimation).

Thirty-seven of the sera were shown to have an abnormal electrolyte balance on biochemical analysis. All the abnormal sera gave " total" electrolyte values either $\overrightarrow{0}$ above or below the figures for the accepted normal range.

The safety of this screening test lies in the fact that all the abnormal sera were detected by this method. It is also interesting to note that where there was an abnormal distribution of electrolytes, that is lowered potassium and raised $\mathrm{CO}_{2}$-combining power, the figures $\stackrel{2}{\circ}$ fall below the accepted range as shown in Fig. 3, even $\stackrel{\mathbb{Q}}{\mathcal{D}}$ though the addition of $\vec{F}$ the values for sodium, $\frac{\text { ? }}{3}$ potassium,chloride, and $\mathrm{CO}_{2}$-combining power gave a figure within the normal range for this $\widehat{O}$ addition, hence the use of inverted commas 3 when referring to the " total" electrolyte figure obtained by our method.

It should be noted that an increase in the blood urea does not affect the resultser obtained by our screen- $N$ ing method.

As already stated, $\omega$ $75 \%$ of the cases which subsequently proved too be normal on biochem- $\bar{\Phi}$ ical analysis fell within? our normal range of $290^{\circ}$ to $310 \mathrm{~m} . \mathrm{Eq} . / \mathrm{l}$. The $\overline{-}$ sera which showed an essentially normal $\stackrel{\odot}{\Phi}$ electrolyte distribution but which were belowe 290 m.Eq. /l. as deter-o 
mined by our electrical method present some interesting problems; possibly these cases are due to over-hydration, and further studies correlating our results with the clinical state of the patient might be informative.

Time is of great importance in a busy biochemistry department, where there is an increasing demand for electrolyte estimations, particularly in post-operative cases. A constant temperature of $37^{\circ} \mathrm{C} .+0.5$ is essential during the estimation, as the results are affected by temperature variations. This method is so simple that, given suitable apparatus, the whole estimation can be completed within a few minutes. Only those bloods with a total electrolyte figure outside the normal range require further analysis.

\section{Summary}

An apparatus for the determination of the electroconductivity of plasma is described. The investigation of 118 samples of plasma confirmed that the normal range for plasma electrolyte values is 290-310 m.Eq./1. Thirty-seven cases which showed an abnormal distribution of electrolytes fell either above or below the normal range.

It is suggested that this method could be used as a screening test to eliminate a large percentage of cases with a normal electrolyte balance, thus relieving the biochemical department of a considerable portion of routine normal investigations.

We are grateful to Dr. E. M. Darmady for his help and encouragement, and to Mr. A. L. Abbott for the biochemical analyses. One of us (E. B.) is grateful to the Royal Free Hospital Medical School Council for the Edith Pechey Phipson Postgraduate Scholarship.

While the results in this paper apparently show that cases with an abnormal electrolyte distribution usually have a total electrolyte value outside the normal range, further work is required before a normal result by conductrimetric methods can be definitely accepted as indicating a normal sodium and potassium distribution in cases where any abnormality might otherwise be anticipated.-ED.

\section{REFERENCES}

Baumann, D. P. (1952). Amer. J. clin. Path., 22, 616.

Black, D. A. K. (1953). Lancet, 1, 305.

Davydoff, S. (1951). Ann. biol. clin., 9, 386.

and Sautier, C. (1952). Ibid., 10, 549.

Domingo, W. R., and Klyne, W. (1949). Biochem. J., 45, 400.

Gornall, A. G., Bardawill, C. J., and David, M. M. (1949). J. biol. Chem., 177, 751.

Graham, G. (1954). The Value of Physiology in Medicine (Harveian Oration Royal College of Physicians). British Medical Association, London.

Lancet (1953). Leading Article, Vol. 1, p. 425.

Schales, O., and Schales, S. S. (1941). J. biol. Chem., 140, 879.

Van Slyke, D. D., and Cullen, G. E. (1917). Ibid., 30, 289.

Wynn, V., and Rob, C. G. (1954). Lancet, 1, 587.

\section{The Estimation of Peptidase Activity in the White Blood Cells by Paper Chromatography}

\author{
F. NOUR-ELDIN AND JOHN F. WILKINSON
}

From the Department of Haematology, Roval Infirmary, and Uiversity of Manchester

(RECEIVED FOR PUBLICATION JULy 5, 1955)

Following our observations on the amino-acid content of white blood cells in human leukaemias (Nour-Eldin and Wilkinson, 1955), it appeared of interest to examine the content of enzymes related to amino-acid metabolism in these cells. Quantitative paper chromatography (Fowden, 1951) was proposed as a method for estimating the amino-acid released by hydrolysation of the substrate when testing peptidase activity.

The occurrence of proteolytic enzymes in the cells of purulent exudates was first demonstrated by Müller (1888). Longcope and Donhauser (1908) reported that the blood of patients with marked leucocytosis seemed to contain enzymes capable of digesting coagulated blood serum. That the white blood cells contained peptidases was demonstrated by Husfeldt (1931) and by Oelkers (1931). Stern, Birmingham, Cullen, and Richer (1951) showed that the peptidase activity of packed white blood cells was nearly five and 500 times that of red blood cells. and plasma, respectively, and was higher in senile people than in young individuals.

In the present paper the peptidase activity in the white blood cells obtained from normal individuals and cases of leukaemia and Hodgkin's disease is determined, using paper chromatography for the estimation of the aminoacids arising from the hydrolysis of the substrates.

\section{Experimental}

Leucocytes. - The white blood cells were separated by the method of Minor and Burnett (1948).

Substrates.-The substrates used were glycylglycine (G.G.), glycylglycylglycine (G.G.G.), and leucylglycylglycine (L.G.G.).

Extraction of Peptidases.-The white blood cells were extracted by such a quantity of $30 \%$ glycerol that each $0.1 \mathrm{ml}$. of the final extract was derived from two million cells. The extraction was carried out for four hours at room temperature.

Reaction Mixture.-This was prepared in well-stoppered $8 \mathrm{~mm}$. tubes. It comprised $1 \mathrm{ml} .0 .1 \mathrm{M}$ substrate, $0.2 \mathrm{ml}$. $0.01 \mathrm{M}$ cobalt sulphate, $0.2 \mathrm{ml}$. glycerol extract of white blood cells, $0.3 \mathrm{ml}$. distilled water, and $0.3 \mathrm{ml}$. 